\title{
PERILAKU PENGGUNAAN MINYAK GORENG SERTA PENGARUHNYA TERHADAP KEIKUTSERTAAN PROGRAM PENGUMPULAN MINYAK JELANTAH DI KOTA BOGOR
}

\author{
Analysis of the Behaviour Effects in Using Cooking Oil on the Participation Program of \\ Collecting the Used Cooking Oil in Bogor City
}

\author{
FIRINA AMALIA ${ }^{1}$, RETNANINGSIH ${ }^{2}$, IRNI RAHMAYANI JOHAN² ${ }^{2 *}$ \\ ${ }^{1}$ Departemen Ilmu Keluarga dan Konsumen, Fakultas Ekologi Manusia, Institut Pertanian \\ Bogor, Kampus Dramaga, Bogor 16680 \\ ${ }^{2}$ Staf Pengajar Departemen IImu Keluarga dan Konsumen, Fakultas Ekologi Manusia, \\ Institut Pertanian Bogor, Jalan Lingkar Kampus IPB Dramaga, Bogor 16680
}

\begin{abstract}
The specific objectives of the study are to: (1) determine the behavior of buying and using the cooking oil, (2) analyze the influence of internal factors on the amount of purchased and utilized the cooking oil, and (3) analyze the affecting factors on house wives' participation on the program of collecting used cooking oil. Result of the study indicates that house wives' purchase on unbranded in plastic package cooking oil daily in small store around the house. The daily average of using cooking oil is about 49,05 gram per capita. Most of them use cooking oil twice for frying. House wives have general knowledge about cooking oil, but they are unaware about the program of collecting the used cooking oil. Several factors, such as family size, wives employment status, and attitude toward cooking oil, significantly determine the behavior of buying and using the cooking oil. This means that the family size knowledge about the program and attitude toward cooking oil gain influence house wives' participation on the program of collecting the used cooking oil.
\end{abstract}

Key words: cooking oil, internal factors, purchasing behavior, usage behavior, waste cooking oil collecting program

\section{PENDAHULUAN}

Minyak adalah komponen yang penting dalam menu manusia dan mampu memenuhi beberapa fungsi gizi. Minyak merupakan sumber energi yang padat (9 kal/gr) dan dapat membantu meningkatkan densitas kalori pada makanan. Minyak goreng adalah minyak yang telah mengalami proses pemurnian yang meliputi degumming, netralisasi, pemucatan, dan deodorisasi (Winarno 1999).

Pada pengolahan pangan, minyak goreng mampu berfungsi sebagai penghantar panas, pemberi cita rasa, perbaikan tekstur makanan, dan penambah nilai gizi (Winarno 1997). Penggunaan minyak goreng untuk memasak sehari-hari sudah melekat di masyarakat karena makanan yang digoreng memiliki rasa yang lebih lezat dan gurih dibandingkan dengan makanan yang direbus, dikukus, atau dipanggang. Hal ini membuat sebagian besar masyarakat khususnya ibu rumah tangga dan penjual makanan sangat tergantung dengan minyak goreng.

Masih cukup tingginya harga minyak goreng bagi sebagian masyarakat dan kurangnya pengetahuan membuat masyarakat sering kali menggunakan minyak goreng yang telah dipakai hingga berulang kali. Kebiasaan menggunakan minyak goreng bekas di masyarakat ini juga karena adanya pendapat bahwa makanan yang dicampur dengan jelantah lebih sedap dan mahalnya harga minyak goreng.

Minyak goreng sisa memasak atau yang dikenal dengan minyak jelantah belum mendapat perhatian khusus dari masyarakat. Perilaku penggunaan minyak goreng di masyarakat yang memiliki kecenderungan untuk dihabiskan dengan cara memakainya berulang kali atau menyisakan minyak yang sudah tidak layak pakai untuk dibuang ke saluran air atau pekarangan, dapat menimbulkan dampak negatif untuk kesehatan dan lingkungan karena minyak yang dipakai berulang kali dapat berpotensi 
untuk menimbulkan penyakit kanker dan penyempitan pembuluh darah yang dapat memicu penyakit jantung koroner, stroke, serta hipertensi, sedangkan menyisakan minyak jelantah untuk dibuang ke saluran air atau pun ke pekarangan dapat menimbulkan pencemaran air dan rusaknya kesuburan tanah.

Minyak jelantah sebenarnya dapat dimanfaatkan sebagai bahan baku biodiesel yang merupakan sumber energi alternatif pengganti solar. Berdasarkan potensi tersebut Pemerintah Kota Bogor mengembangkan program pengumpulan minyak jelantah. Program ini bertujuan untuk mengubah perilaku masyarakat yang sering menggunakan minyak jelantah untuk memasak, membuang minyak jelantah ke lingkungan, dan untuk memanfaatkan minyak jelantah sebagai bahan baku alternatif pengganti solar pada Bus Trans Pakuan. Program ini masih dinilai kontroversial dan memiliki hambatan karena tidak mudah untuk mengubah perilaku masyarakat. Walaupun sudah dua tahun program ini berjalan, partisipasi masyarakat masih rendah. Hal ini diduga karena kebiasaan masyarakat yang cenderung untuk menghabiskan minyak jelantah ketika memasak atau membuang minyak jelantah ke saluran air dan pekarangan.

Secara umum penelitian ini bertujuan untuk menganalisis perilaku penggunaan minyak goreng serta pengaruhnya terhadap program pengumpulan minyak jelantah di Kota Bogor. Tujuan khusus: (1) mengidentifikasi perilaku pembelian dan penggunaan minyak goreng; (2) menganalisis pengaruh faktor internal terhadap jumlah pembelian dan penggunaan minyak goreng; dan (3) menganalisis faktor-faktor yang berpengaruh terhadap program pengumpulan minyak jelantah.

\section{METODE}

\section{Desain, Lokasi, dan Waktu}

Desain penelitian ini adalah Cross Sectional Study. Penelitian dilaksanakan pada tahun 2009, di Kelurahan Cikaret, Kecamatan Bogor Selatan, Kota Bogor. Pemilihan lokasi penelitian dilakukan secara purposive dengan pertimbangan bahwa Kelurahan Cikaret sudah rutin ikut serta dalam program pengumpulan minyak jelantah yang dilaksanakan oleh Pemerintah Kota Bogor.
Teknik Penarikan Contoh

Penarikan contoh dilakukan secara convenience sampling berdasarkan kesediaan contoh untuk diwawancara, sedangkan jumlah contoh dibagi di dalam kelompok berdasarkan RW dan jumlah contoh ditentukan secara proporsional.

Kelurahan Cikaret terdiri dari $12 \mathrm{RW}$ dengan jumlah total kepala keluarga yaitu $3.653 \mathrm{KK}$. Berdasarkan perhitungan dengan menggunakan rumus Slovin maka jumlah contoh untuk penelitian adalah 120 rumah tangga.

\section{Jenis dan Teknik Pengumpulan Data}

Data penelitian yang dikumpulkan berupa data primer dan data sekunder. Data primer dalam penelitian ini diperoleh melalui wawancara kuesioner. Sedangkan data sekunder yang diperoleh dari instansi terkait.

\section{Pengolahan dan Analisis Data}

Data diolah dengan menggunakan Microsoft Excel for Mac dan SPSS for Windows. Analisis data dilakukan secara statistik deskriptif dan statistik inferensia (uji regresi linier berganda dan regresi logistik).

\section{HASIL DAN PEMBAHASAN}

\section{Karakteristik Keluarga Contoh}

Usia suami berkisar antara 25 tahun sampai dengan 73 tahun dan istri berkisar antara 21 tahun sampai dengan 70 tahun. Rata-rata umur istri adalah 41,4 tahun dan rata-rata umur suami adalah 41,2 tahun. Berdasarkan Hurlock (1980) dapat diketahui bahwa lebih dari separuh usia suami (56\%) berada pada fase dewasa madya dan lebih dari separuh usia istri $(52,5 \%)$ berada pada fase dewasa muda. Pendidikan suami dan istri pada penelitian ini berkisar antara tidak sekolah hingga tamat perguruan tinggi. Persentase terbesar pendidikan suami $(29,4 \%)$ dan pendidikan istri $(31,4 \%)$ adalah tamat SD. Tingkat pendidikan seseorang akan menentukan jenis pekerjaan yang dilakukan seseorang (Sumarwan 2004). Persentase terbesar suami (44\%) memiliki pekerjaan sebagai buruh, sedangkan persentase terbesar istri (75\%) tidak memiliki pekerjaan atau sebagai ibu rumah tangga,

Jumlah anggota keluarga akan menentukan jumlah dan pola konsumsi suatu barang dan jasa (Sumarwan 2004). Sebagian besar contoh (72,5\%) merupakan keluarga sedang yang memiliki jumlah anggota keluarga antara 5-7 orang. 
Pendapatan per kapita per bulan contoh berkisar antara $\mathrm{Rp} 191.000,00$ sampai dengan $\mathrm{Rp} 1.450 .000,00$. Rata-rata pendapatan per kapita per bulan yang diperoleh contoh adalah Rp 247.816,00 dimana persentase terbesar contoh $(48,3 \%)$ memiliki pendapatan per kapita per bulan kurang dari Rp 191.000,00. Berdasarkan garis kemiskinan Jawa Barat tahun 2008, sebesar 48,3\% contoh tergolong dalam kategori miskin.

\section{Perilaku Pembelian Minyak Goreng}

Perilaku pembelian merupakan fungsi dari niat pembelian dan pengaruh lingkungan dan atau perbedaan individu (Engel et al. 1994). Kebiasaan pembelian minyak goreng setiap rumah tangga berbeda-beda. Sekitar $65,8 \%$ contoh membeli minyak goreng secara harian dan hanya $8,4 \%$ contoh membeli minyak goreng secara bulanan. Jumlah pembelian minyak goreng akan menentukan besarnya pengeluaran yang dikeluarkan oleh contoh untuk membeli minyak goreng. Rata-rata biaya yang dikeluarkan contoh untuk membeli minyak goreng setiap bulan adalah sebesar Rp 72.153,00.

Sebagian besar contoh (85,8\%) membeli minyak goreng tanpa merek (minyak curah) dengan alasan karena harga minyak curah yang murah sehingga sesuai dengan pendapatan contoh dan minyak curah dapat dibeli dalam jumlah yang sedikit. Selain itu, sebagian besar contoh $(84,1 \%)$ membeli minyak goreng di warung dan yang paling sering melakukan pembelian adalah istri. Hampir seluruh contoh $(96,7 \%)$ memilih minyak goreng yang dikemas dalam kemasan plastik.

Penelitian yang dilakukan Hurriani (2005) pada rumah tangga miskin dan tidak miskin di Kota Bogor, juga menunjukkan hal serupa yakni bahwa pada pertimbangan pembelian, mayoritas contoh $(66,7 \%$ miskin dan $60 \%$ tidak miskin) memiliki kebiasaan membeli minyak goreng dengan frekuensi harian, sebagian besar contoh $(86,7 \%$ miskin dan $93,4 \%$ tidak miskin) memilih minyak goreng curah, dengan kemasan kantong plastik bening transparan dan tempat pembelian yang dipilih $(76,7 \%$ miskin dan $83,4 \%$ tidak miskin) adalah warung terdekat.

\section{Perilaku Penggunaan Minyak Goreng}

Penggunaan minyak goreng di rumah tangga sangat bervariasi, tetapi tidak semua rumah tangga menggunakan minyak goreng setiap hari untuk memasak. Hampir seluruh contoh (92,5\%) pada penelitian ini menggunakan minyak goreng untuk memasak setiap harinya, contoh yang tidak menggunakan minyak goreng untuk memasak setiap hari biasanya menggunakan minyak goreng empat kali dalam satu minggu. Minyak goreng tidak hanya digunakan untuk memasak tetapi minyak goreng juga digunakan untuk memijat. Ratarata jumlah penggunaan minyak goreng adalah 49,05 $\mathrm{g} / \mathrm{kap} / \mathrm{hr}$ namun jumlah ini belum dikoreksi dengan jumlah minyak goreng yang tidak digunakan untuk rumah tangga dan minyak goreng yang dibuang sebagai sampah.

Pemakaian minyak goreng untuk memasak di rumah tangga terkadang langsung dihabiskan atau mempunyai sisa. Habis atau tidaknya minyak goreng tergantung cara pemakaian masing-masing rumah tangga. Persentase terbesar contoh $(60 \%)$ menggunakan minyak goreng untuk dua kali pemakaian dan hanya sebesar $1,7 \%$ contoh yang menggunakan minyak goreng untuk empat kali pemakaian. Persentase terbesar contoh $(56,7 \%)$ membuang minyak jelantah ke saluran air.

Hasil ini juga sejalan dengan penelitian Krisnandika (2003) tentang preferensi dan persepsi konsumen terhadap minyak goreng pada tingkat rumah tangga, disimpulkan bahwa minyak goreng umumnya digunakan satu hingga dua kali dan setelah itu dibuang. Demikian juga dengan penelitian Hurriani (2005) yang telah disinggung sebelumnya, dimana penggunaan kurang dari dua kali pengulangan minyak goreng contoh pada status miskin dan tidak miskin adalah sebesar $83,3 \%$ dan 56,7\%. Hal ini disebabkan karena pada rumah tangga miskin lebih menghemat minyak, maka penggunaannya lebih sedikit, sehingga minyak sisa yang ada tidak dapat digunakan.

\section{Keikutsertaan dalam Program}

Program pengumpulan minyak jelantah bertujuan untuk mengurangi pemakaian minyak jelantah di masyarakat dan sebagai sumber energi alternatif pengganti solar. Program yang telah dilaksanakan di Kota Bogor sejak tahun 2007 ini belum mendapat mendapat perhatian penuh dari masyarakat. Hal ini ditunjukkan dari rendahnya keikutsertaan masyarakat dalam program ini.

Sebagian besar contoh $(77,3 \%)$ dalam penelitian ini tidak ikut serta dalam program dan hanya sebesar $22,7 \%$ yang ikut serta dalam program. Alasan contoh tidak ikut 
serta dalam program karena jumlah minyak jelantah yang dihasilkan sedikit sehingga sangat sulit untuk mengumpulkannya. Selain itu contoh cenderung untuk membuang minyak jelantah dalam jumlah yang sedikit.

\section{Pengetahuan tentang Minyak Goreng}

Pengetahuan didefinisikan sebagai informasi yang disimpan di dalam ingatan (Engel et al. 1994). Pengetahuan mengenai suatu produk sangat dibutuhkan oleh konsumen agar dapat membeli dan menggunakan produk dengan benar. Tingkat pengetahuan yang dimiliki contoh berbedabeda. Berdasarkan hasil penelitian, sebagian besar contoh $(89,2 \%)$ memiliki tingkat pengetahuan yang baik tentang minyak goreng (Tabel 1) karena sebagian besar pertanyaan yang terkait dengan minyak goreng dapat dijawab dengan benar oleh contoh. Pertanyaan yang diajukan antara lain mengenai asal minyak goreng, bahan baku minyak goreng, frekuensi maksimal menggunakan minyak goreng sisa, pengertian minyak jelantah, ciri minyak goreng rusak, kandungan zat berbahaya dalam minyak jelantah, dan bahaya minyak jelantah untuk kesehatan.

Tabel 1. Sebaran contoh berdasarkan tingkat pengetahuan tentang minyak goreng

\begin{tabular}{lrr}
\hline \multirow{2}{*}{ Kategori Pengetahuan } & \multicolumn{2}{c}{ Jumlah } \\
\cline { 2 - 3 } & n & \multicolumn{1}{c}{$\%$} \\
\hline Kurang (0-6) & 1 & 0,8 \\
Sedang (7-13) & 12 & 10,0 \\
Baik (14-20) & 107 & 89,2 \\
\hline \multicolumn{1}{c}{ Total } & 120 & 100,0 \\
\hline
\end{tabular}

Pengetahuan tentang minyak goreng sangat penting untuk diketahui oleh contoh karena minyak goreng selalu digunakan oleh rumah tangga dalam mengolah pangan sehari-hari. Dalam penelitian ini, pengetahuan tentang minyak goreng diperoleh oleh contoh dari sosialisasi, tetangga, dan pengalaman penggunaan minyak goreng.

\section{Pengetahuan tentang Program}

Selain pengetahuan tentang minyak goreng, contoh juga harus memiliki pengetahuan tentang program pengumpulan minyak jelantah. Pengetahuan ini sangat penting untuk membangun sikap contoh terhadap program pengumpulan minyak jelantah dan menambah pemahaman contoh tentang program. Lebih dari separuh contoh $(53,3 \%)$ memiliki tingkat pengetahuan yang kurang mengenai program (Tabel 2). Pengetahuan tentang program pengumpulan minyak jelantah diduga mempengaruhi sikap dan keikutsertaan contoh dalam program pengumpulan minyak jelantah.

Tabel 2. Sebaran contoh berdasarkan
tingkat pengetahuan tentang
program

\begin{tabular}{lrr}
\hline \multirow{2}{*}{ Kategori Pengetahuan } & \multicolumn{2}{c}{ Jumlah } \\
\cline { 2 - 3 } & $\mathbf{n}$ & \multicolumn{1}{c}{$\%$} \\
\hline Kurang (0-6) & 64 & 53,3 \\
Sedang (7-13) & 35 & 29,2 \\
Baik (14-20) & 21 & 17,5 \\
\hline \multicolumn{1}{c}{ Total } & 120 & 100,0 \\
\hline
\end{tabular}

Informasi tentang program pengumpulan minyak jelantah diperoleh contoh melalui brosur yang ada di kelurahan dan sosialisasi yang sudah dilaksanakan di setiap kelurahan. Tetapi contoh yang berasal dari RW yang jauh dari kelurahan cenderung belum mengetahui tentang program karena informasi tersebut belum sampai ke tempat tinggal contoh. Selain itu, contoh juga belum sepenuhnya mengerti tentang program ini karena sosialisasi yang dilakukan pemerintah belum dilakukan secara intensif. Pengetahuan program ini sangat dibutuhkan oleh contoh agar contoh tidak salah dalam menginterpretasikan program.

\section{Sikap terhadap Minyak Goreng dan Program}

Sikap konsumen merupakan faktor penting yang akan mempengaruhi keputusan konsumen. Konsep sikap sangat terkait dengan konsep kepercayaan dan perilaku (Sumarwan 2004). Sikap adalah kecenderungan pembelajaran untuk merespon suatu objek atau objek kelas secara terus menerus terkait pada hal yang disukai atau tidak disukai (Assael 1992).

Berdasarkan hasil penelitian, hampir seluruh contoh $(97,5 \%)$ memiliki skor sikap dengan kategori netral (21-30). Sikap yang dimiliki contoh sudah cukup baik karena sesuai dengan tingkat pengetahuan yang dimiliki contoh. Sikap yang baik ini diharapkan memiliki kecenderungan untuk menciptakan perilaku yang positif terhadap program pengumpulan minyak jelantah dengan cara ikut berpartisipasi. Sebaran contoh berdasarkan kriteria sikap terhadap program dapat dilihat pada Tabel 3. 
Tabel 3. Sebaran contoh berdasarkan kriteria sikap terhadap program

\begin{tabular}{lrr}
\hline \multirow{2}{*}{ Kriteria Sikap } & \multicolumn{2}{c}{ Jumlah } \\
\cline { 2 - 3 } & \multicolumn{1}{c}{$\mathbf{n}$} & \multicolumn{1}{c}{$\%$} \\
\hline Negatif $(10-20)$ & 0 & 0,0 \\
Netral $(21-30)$ & 117 & 97,5 \\
Positif $(31-40)$ & 3 & 2,5 \\
\hline Total & 120 & 100,0 \\
\hline
\end{tabular}

\section{Pengaruh Faktor Internal terhadap Jumlah Pembelian dan Penggunaan Minyak Goreng}

Jumlah pembelian dan penggunaan minyak goreng tergantung dari kebutuhan masing-masing. Hasil uji regresi linier berganda menunjukkan bahwa tidak semua variabel bebas memiliki nilai yang signifikan. Nilai Adjusted $R$ Square untuk model ini adalah 0,136 . Hal ini berarti sebesar $13,6 \%$ jumlah pembelian dan penggunaan minyak goreng dapat diterangkan oleh faktor internal dan sisanya $86,4 \%$ dijelaskan oleh variabel lain. Variabel yang berpengaruh nyata dengan jumlah pembelian dan penggunaan minyak goreng adalah jumlah anggota keluarga, skor sikap, dan pekerjaan istri (Tabel 4).

Tabel 4. Pengaruh faktor internal terhadap jumlah pembelian dan penggunaan minyak goreng

\begin{tabular}{|c|c|c|}
\hline & B & Sig \\
\hline Constant & 1,062 & 0,013 \\
\hline Jumlah anggota keluarga & 0,048 & $0,001^{* *}$ \\
\hline Usia ibu rumah tangga & $-0,003$ & 0,240 \\
\hline Pendidikan ibu rumah tangga & $-0,153$ & 0,227 \\
\hline Pendapatan & 2,24E-08 & 0,468 \\
\hline $\begin{array}{l}\text { Skor pengetahuan minyak } \\
\text { goreng }\end{array}$ & 0,002 & 0,825 \\
\hline Skor sikap & $-0,003$ & $0,029 *$ \\
\hline $\begin{array}{l}\text { Dummy pekerjaan suami } \\
\text { (1=bekerja; } 0=\text { tidak bekerja) }\end{array}$ & 0,024 & 0,777 \\
\hline $\begin{array}{l}\text { Dummy pekerjaan istri } \\
\text { (1=pedagang; } 0=\text { bukan } \\
\text { pedagang) }\end{array}$ & 0,110 & $0,041^{*}$ \\
\hline R Square & \multicolumn{2}{|c|}{0,194} \\
\hline Adjusted R Square & \multicolumn{2}{|c|}{0,136} \\
\hline $\begin{array}{ll}\text { Ket: } & { }^{* *} \text { signifikan pad } \\
& * \text { signikan pada }\end{array}$ & $\begin{array}{l}0,01 \\
05\end{array}$ & \\
\hline
\end{tabular}

Faktor-faktor yang Berpengaruh terhadap Program Pengumpulan Minyak Jelantah

Hasil uji regresi logistik menunjukkan bahwa tidak semua variabel bebas memiliki nilai yang signifikan. Nilai Negelkerke $R$ Square yang dihasilkan oleh model adalah sebesar 0,422 . Hal ini berarti sebesar $42,2 \%$ keikutsertaan dalam program dapat dijelaskan oleh variabel bebas pada model dan sisanya $57,8 \%$ dijelaskan oleh variabel lain. Variabel yang berpengaruh nyata terhadap program pengumpulan minyak jelantah adalah jumlah anggota keluarga, skor pengetahuan program, dan skor sikap (Tabel 5).

Tabel 5. Faktor-faktor yang berpengaruh terhadap program pengumpulan minyak jelantah

\begin{tabular}{|c|c|c|c|}
\hline & B & Sig & $\begin{array}{l}\text { Exp } \\
\text { (B) }\end{array}$ \\
\hline Jumlah anggota keluarga & 0,459 & $0,036^{\star *}$ & 1,583 \\
\hline Usia ibu rumah tangga & $-0,002$ & 0,961 & 0,998 \\
\hline $\begin{array}{l}\text { Pendidikan ibu rumah } \\
\text { tangga }\end{array}$ & $-0,336$ & 0,314 & 0,714 \\
\hline Pendapatan & 0 & 0,196 & 1 \\
\hline $\begin{array}{l}\text { Skor pengetahuan minyak } \\
\text { goreng }\end{array}$ & 0,261 & 0,118 & 1,298 \\
\hline Skor pengetahuan program & 0,109 & $0,064^{*}$ & 1,115 \\
\hline Skor sikap & 0,488 & $0,060^{*}$ & 1,629 \\
\hline Dummy pekerjaan KK & 1,888 & 0,238 & 6,581 \\
\hline $\begin{array}{l}\text { Dummy pekerjaan ibu } \\
\text { rumah tangga }\end{array}$ & 0,796 & 0,308 & 2,216 \\
\hline Frekuensi pembelian & 0,280 & 0,767 & 1,323 \\
\hline Tempat pembelian & 0,553 & 0,538 & 1,738 \\
\hline Jenis minyak goreng & $-0,446$ & 0,568 & 0,628 \\
\hline Jenis kemasan & $-0,248$ & 0,895 & 0,781 \\
\hline Biaya yang dikeluarkan & 0 & 0,654 & 1 \\
\hline Pelaku pembelian & $-1,691$ & 0,281 & 0,184 \\
\hline Frekuensi penggunaan & 0,281 & 0,804 & 1,325 \\
\hline Jumlah yang digunakan & $-5,191$ & 0,282 & 0,006 \\
\hline Kebiasaan menghabiskan & 0,869 & 0,358 & 0,419 \\
\hline Konstanta & $-19,790$ & 0,036 & 0 \\
\hline 2 Log Likelihood & \multicolumn{3}{|c|}{73,476} \\
\hline Cox \& Snell R Square & \multicolumn{3}{|c|}{0,201} \\
\hline Nagelkerke R Square & \multicolumn{3}{|c|}{0,422} \\
\hline $\begin{array}{ll}\text { Ket: } & \text { ** signifikan p } \\
& { }^{*} \text { signikan pac }\end{array}$ & $\begin{array}{l}x=0,0 \\
0,1\end{array}$ & & \\
\hline
\end{tabular}

Semakin bertambahnya skor sikap yang dimiliki contoh berpengaruh nyata terhadap meningkatnya peluang keikutsertaan contoh dalam program pengumpulan minyak jelantah sebesar 1,629 kali. Peningkatan skor pengetahuan program berpengaruh nyata terhadap meningkatnya peluang keikutsertaan contoh dalam program pengumpulan minyak jelantah sebesar 1,115 kali. Oleh karena itu, pengetahuan mengenai program pengumpulan minyak jelantah dapat mendukung untuk menimbulkan sikap positif pada contoh karena pengetahuan yang dimiliki contoh terkait dengan komponen kognitif dalam sikap yang dapat membantu untuk membentuk kesadaran diri contoh yang selanjutnya menimbulkan keinginan untuk ikut serta dalam program pengumpulan minyak jelantah.

Tabel 5 juga menunjukkan bahwa peningkatan jumlah anggota keluarga berpengaruh nyata terhadap meningkatnya peluang keikutsertaan contoh dalam program 
pengumpulan minyak jelantah sebesar 1,583 kali. Jumlah anggota keluarga yang banyak berpengaruh terhadap jumlah pembelian dan penggunaan minyak goreng sehingga cenderung untuk memiliki sisa minyak goreng yang cukup banyak dan pada akhirnya dapat meningkatkan peluang contoh untuk ikut serta terhadap program.

\section{KESIMPULAN DAN SARAN}

\section{Kesimpulan}

Contoh membeli minyak goreng harian. Jenis minyak goreng yang dibeli adalah minyak curah yang dibeli di warung. Contoh membeli minyak goreng yang dikemas dalam kemasan plastik dan yang paling sering melakukan pembelian adaalh istri.

Rata-rata penggunaan minyak goreng adalah 49,05 gram/kap/hari. Selain untuk memasak, minyak goreng digunakan contoh untuk memijat. Persentase terbesar contoh menggunakan minyak goreng untuk dua kali pemakaian. Setelah itu, contoh membuang minyak jelantah dan hanya sedikit contoh yang ikut serta dalam program pengumpulan minyak jelantah.

Faktor internal yang berpengaruh terhadap jumlah pembelian dan penggunaan minyak goreng adalah jumlah anggota keluarga, pekerjaan istri, dan skor sikap. Faktor-faktor yang berpengaruh terhadap program pengumpulan minyak jelantah adalah jumlah anggota keluarga, skor pengetahuan program, dan skor sikap.

\section{Saran}

Perlu adanya sosialisasi mengenai program pengumpulan minyak jelantah dan mengenai kemajuan pelaksanaan program secara intensif serta berkelanjutan kepada masyarakat. Selain itu, perlu adanya sanksi bagi pedagang yang menjual minyak jelantah kepada masyarakat. Sasaran dari program ini sebaiknya hotel, restoran, dan pedagang makanan karena masyarakat tidak menghasilkan minyak jelantah dalam jumlah yang banyak. Selain itu, perlu penelitian lanjutan mengenai penggunaan minyak goreng oleh hotel, restoran, dan produsen makanan.

\section{DAFTAR PUSTAKA}

Assael H. 1992. Consumer Behavior and Marketing Action ( $4^{\text {th }}$ ed). Boston: PWSKent Publishing Company.

Engel JF, Blackwell RD, Miniard PW. 1994. Perilaku Konsumen ( $6^{\text {th }}$ ed). Jilid kesatu. FX Budiyanto, penerjemah. Jakarta: Binarupa Aksara.

Hurlock EB. 1980. Psikologi Perkembangan. Edisi kelima. Jakarta: Erlangga.

Hurriani, V. 2005. Pembelian, Penggunaan, Penyimpanan dan Konsumsi Minyak Goreng pada Rumahtangga Miskin dan Tidak Miskin di Kota bogor serta Estimasi Level Fortifikan. Skripsi. Program Studi Gizi Masyarakat dan Sumberdaya Keluarga, Fakultas Pertanian, Institut Pertanian Bogor.

Krisnandika, A. 2003. Preferensi dan Persepsi Konsumen terhadap Minyak Goreng pada Tingkat rumah Tangga. Skripsi. Program Studi Gizi Masyarakat dan Sumberdaya Keluarga, Fakultas Pertanian, Institut Pertanian Bogor.

Sumarwan U. 2004. Perilaku Konsumen: Teori dan Penerapannya dalam Pemasaran. Bogor: Ghalia Indonesia.

Winarno FG. 1997. Kimia Pangan dan Gizi. Jakarta: Gramedia Pustaka Utama. . 1999. Minyak Goreng dalam Menu Masyarakat. Jakarta: Balai Pustaka.

\footnotetext{
* Korespondensi :

Telp : +62-251 8628303

Email : irnisatia@yahoo.com
} 